Research Report No. 44/2008

\title{
A Principled Approach to Reforming the Canadian Outbound Tax System: Broader Accrual and Full Exemption
}

Jinyan Li

Osgoode Hall Law School of York University, JLi@osgoode.yorku.ca

Follow this and additional works at: http:// digitalcommons.osgoode.yorku.ca/clpe

\section{Recommended Citation}

Li, Jinyan, "A Principled Approach to Reforming the Canadian Outbound Tax System: Broader Accrual and Full Exemption" (2008). Comparative Research in Law \& Political Economy. Research Paper No. 44/2008.

http://digitalcommons.osgoode.yorku.ca/clpe/213 


\section{$J$ inyan Li}

A Principled Approach to Reforming the Canadian Outbound Tax System: Broader Accrual and Full Exemption

This paper has been published in Tax Notes International, November 2008

EDTORS: Peer Zumbansen (Osgoode Hall Law School, Toronto, Director, Comparative Research in Law and Political Economy, York University), J ohn W. Cioffi (University of California at Riverside), Lindsay Krauss (Osgoode Hall Law School, Toronto, Production Editor) 

CLPE Research Paper 44/2008

Vol. 04 No. 08 (2008)

\title{
Jinyan Li
}

\section{A Principled Approach to Reforming the Canadian OUTBOUND TAX SYSTEM: BROADER ACCRUAL AND FULL EXEMPTION}

\begin{abstract}
This article is based on a submission to the Advisory Panel of Canada's System of International Taxation. It discusses the general approach to tax reform and the specific questions about redesigning the outbound tax system. The main thesis is that the neutrality theories (CIN, CEN and CON) are not particularly determinative or even that useful in thinking about the reform questions in Canada. A principled approach along the lines of fundamental tax principles and tax expenditure analysis should be seriously considered. The ability-to-pay and tax entitlement are fundamental principles underlying the existing outbound tax system. No serious suggestion has been made anywhere that the re-designed system should be fundamentally different. As such, these principles should continue to apply. Situating the exemption system as part of the normative system as opposed to a tax expenditure may redirect the debate to some different questions. This article supports a broader accrual system for foreign portfolio income and a full exemption of dividends received from “foreign affiliates" of Canadian resident corporations.
\end{abstract}

Keywords: Territorial taxation, exemption system, credit system, capital import neutrality, capital export neutrality, capital ownership neutrality, territorial principle of taxation, ability to pay, foreign portfolio income, foreign business income

JEL classification: K34

Author Contact:

Jinyan Li

Osgoode Hall Law School, York University

4700 Keele St, Toronto Ontario, M3J 1P3

Email: jli@osgoode.yorku.ca 


\title{
A Principled Approach to Reforming the CANADIAN OUTBOUND TAX SYSTEM: BROADER ACCRUAL AND FULL EXEMPTION
}

\author{
Jinyan $\mathrm{Li}^{*}$
}

\section{INTRODUCTION}

The Advisory Panel of Canada's System of International Taxation (the "Panel”) published its consultation paper in April 2008, entitled Enhancing Canada's International Tax Advantage. ${ }^{1}$ The Panel's mandate is "to make recommendations to guide the government in establishing an international tax policy framework," as well as "to improve the competitiveness, efficiency and fairness of Canada's system of international taxation, minimize compliance costs for businesses, and facilitate administration and enforcement by the Canada Revenue Agency." The Consultation Paper identifies the policy framework to include attracting foreign investment, competitiveness, simplicity, and fairness. It recognizes that capital export neutrality (CEN), capital import neutrality (CIN) and capital ownership neutrality (CON) may influence the choice between an exemption system and a foreign tax credit system. ${ }^{2}$ The Panel expressed a preference for a broader exemption system.

\footnotetext{
* The authored benefited from discussions with Scott Wilkie and comments from Neil Brooks on an earlier draft. She thanks them for their insights, but does not wish to attribute any of the specific views to either of them. The author also thanks He Huang, LL.M candidate at Osgoode, and Shane Litvack, BLG Fellow, for their research assistance.

${ }^{1}$ The Consultation paper is available at www.apcsit-gcrcfi.ca.

${ }^{2}$ The CEN generally requires current taxation of foreign income with a full credit for foreign taxes paid. To the extent that foreign taxes are less than domestic tax, the tax base is shared between the source country and the residence country of the shareholder. CIN and CON call for the primary or exclusive taxation of business income in the source country. This is often referred to as the "exemption" system or territorial system. In practice, no country has adopted a pure credit system or a pure exemption system. The mix of the two systems attempts to balance between CEN and CIN/CON.
} 
[VOL. 04 No. 08

This article discusses the general approach to tax reform and the specific questions about redesigning the outbound tax system. The main thesis is that the neutrality theories (CIN, CEN and CON) are not particularly determinative or even that useful in thinking about the reform questions. A principled approach along the lines of fundamental tax principles and tax expenditure analysis should be seriously considered. The ability-to-pay and tax entitlement are fundamental principles underlying the existing outbound tax system. No serious suggestion has been made anywhere that the re-designed system should be fundamentally different. As such, these principles should continue to apply. Situating the exemption system as part of the normative system as opposed to a tax expenditure may redirect the debate to some different questions. This article supports a broader accrual system for foreign portfolio income and a full exemption of dividends received from “foreign affiliates” of Canadian resident corporations.

\section{OVERVIEW OF THE CURRENT SYSTEM}

The current outbound tax system contains many complex rules that look at the character of foreign income and whether the income is earned directly or indirectly through a foreign intermediary (typically a corporation). Income earned directly by resident taxpayers (individuals and corporations alike) is currently taxable, subject to relief for foreign taxes. ${ }^{3}$ Income earned through a foreign corporation is taxed in Canada in a variety of ways, depending on whether: the foreign corporation is a "foreign affiliate" (FA), the FA is resident in a treaty country, the foreign income earned by the FA is "foreign accrual property income" (FAPI) or active business income, the FA is "controlled” by a Canadian resident (CFA), and the Canadian shareholder is a corporation or an individual.

Generally speaking, income earned through a foreign affiliate is "deferred" from Canadian tax until the corporation pays dividends to its Canadian shareholder. If the shareholder is a Canadian corporation, the dividends are taxed differently depending on the character of income and whether the foreign country has a tax treaty with Canada. Dividends are

${ }^{3}$ S.2(1), s.3 and s.126 of the Canadian Income Tax Act (ITA). 
"exempt" if the foreign affiliate is in a treaty country and the income is derived from active businesses (the "exemption system”). ${ }^{4}$ Dividends are "taxable" in other cases with relief for foreign withholding tax on the dividends as well as the foreign underlying corporate tax (the "deferral with credit" system). ${ }^{5}$

The character of the foreign income earned by a foreign affiliate generally determines the application of the accrual system or the deferral system: FAPI is subject to accrual, non-FAPI is eligible for deferral. Within the deferral system, the character of foreign income as well as the existence or absence of a tax treaty determines whether the dividends are subject to the exemption treatment or the credit treatment. ${ }^{6}$

\section{A. Foreign ACTIVE Business INCOME}

Foreign active business income earned directly by a Canadian resident individual (CRI) or Canadian resident corporation (Canco) is currently taxed in Canada, subject to foreign tax credit relief. On the other hand, foreign business income earned through a foreign corporation is not taxable in Canada when the income is earned. Canadian tax is deferred until the foreign corporation pays dividends to Canadian shareholders. The dividends may be taxed as:

(a) ordinary "non-business income" where the foreign corporation does not qualify as a "foreign affiliate" or where the shareholder is an individual;

(b) “exempt dividends" where the foreign corporation is a foreign affiliate resident in a country that has a tax treaty or Tax Information Exchange Agreement (TIEA) with Canada and the shareholder is a Canadian corporation (the "exemption system”);

(c) "taxable dividends" where the foreign affiliate is in a non-treaty country and the shareholder is a Canadian corporation (the “deferral with credit” system).

\footnotetext{
${ }^{4} \mathrm{~S} .90$ and $\mathrm{s.113(1)(a)}$ of the ITA.

${ }^{5} \mathrm{~S} .90$ and s.113(1)(b)(c) of the ITA.

${ }^{6}$ S.113(1)(b)(c) of the ITA.
} 
Under the "exemption system", foreign taxes are not recognized in Canada. Under the credit system, Canada provides a direct foreign tax credit for withholding tax and an indirect credit for the underlying corporate tax. In practice, however, taxable dividends are not actually taxed in Canada after the deduction for direct and indirect foreign tax credits. $^{7}$

Table 1: Canadian taxation of foreign active business income earned through a foreign corporation (FC)

\begin{tabular}{|l|l|l|l|}
\hline \multicolumn{1}{|c|}{ Status of FC } & $\begin{array}{l}\text { FA in treaty } \\
\text { Canadian } \\
\text { investor }\end{array}$ & $\begin{array}{l}\text { FA in non- } \\
\text { treaty country }\end{array}$ & Non-FA \\
\hline $\begin{array}{l}\text { CRI } \\
\text { - current tax on FC's } \\
\text { income? } \\
\text { - tax on dividends from FC? }\end{array}$ & $\begin{array}{l}\text { No, not within s.2(1) or } \\
\text { Y) } \\
\text { Yes, s.126 relief }\end{array}$ & $\begin{array}{l}\text { No } \\
\text { Yes, s.126 relief }\end{array}$ & $\begin{array}{l}\text { No } \\
\text { Yes, s.126 } \\
\text { relief }\end{array}$ \\
\hline $\begin{array}{l}\text { Canco } \\
\text { - current tax on FC's } \\
\text { income? } \\
\text { - tax on dividends from FC? }\end{array}$ & $\begin{array}{l}\text { No } \\
\text { No, s.113(1)(a) }\end{array}$ & $\begin{array}{l}\text { No } \\
\text { Yes, } \\
\text { s.113(1)(b)(c) } \\
\text { relief }\end{array}$ & $\begin{array}{l}\text { Nos, s.126 } \\
\text { relief }\end{array}$ \\
\hline
\end{tabular}

\section{B. FOREIGN ACCRUAL PROPERTY INCOME (FAPI)}

FAPI earned through a foreign corporation is subject to accrual taxation in Canada, but only if the foreign corporation is a CFA or a "foreign investment entity" (FIE) (i.e., the income is derived primarily from portfolio investment) of a Canadian corporation or individual. In other cases, the deferral treatment applies to FAPI as well. Dividends paid out of FAPI are "taxable dividends", eligible for direct and indirect foreign tax credits. To the extent that the FAPI is taxed on an accrual basis, the dividends paid out of pre-taxed FAPI are generally "tax-free” in Canada. ${ }^{8}$

\footnotetext{
${ }^{7}$ According to some practitioners, why would anyone bring back taxable dividends if they end up being taxed in Canada. The Consultation Paper indicates (at 14) that there is no reliable data showing the amount of Canadian tax actually collected on taxable dividends.

${ }^{8}$ S.91(5) and s.113(1)(b)(c) of ITA.
} 
Table 2: Canadian taxation of FAPI earned through a foreign corporation (FC)

\begin{tabular}{|c|c|c|c|}
\hline$\underbrace{\text { Status of FC }}_{\text {Canadian investor }}$ & CFA & $\begin{array}{l}\text { FA but non- } \\
\text { CFA }\end{array}$ & Non-FA \\
\hline $\begin{array}{l}\text { CRI } \\
\text { - Accrual tax of FAPI? } \\
\text { - dividends from FC taxable? }\end{array}$ & $\begin{array}{l}\text { Yes, s.91(4) relief } \\
\text { Yes, s.126 FTC }\end{array}$ & $\begin{array}{l}\text { No } \\
\text { Yes, s.126 FTC }\end{array}$ & $\begin{array}{l}\text { No } \\
\text { Yes, s.126 } \\
\text { FTC }\end{array}$ \\
\hline $\begin{array}{l}\text { Canco } \\
\text { - Accrual tax of FAPI? } \\
\text { - dividends from FC taxable? }\end{array}$ & $\begin{array}{l}\text { Yes, s.91(4) and (5) relief } \\
\text { Yes, s.113(1)(b)(c) relief }\end{array}$ & $\begin{array}{l}\text { No. } \\
\text { Yes, } \\
\text { s.113(1)(b)(c) } \\
\text { relief }\end{array}$ & $\begin{array}{l}\text { No. } \\
\text { Yes, s.126 } \\
\text { relief }\end{array}$ \\
\hline
\end{tabular}

\section{BASIC STRUCTURE}

In summary, the Canadian outbound tax system contains the following basic elements:

a) Worldwide taxation of residents on foreign income earned directly;

b) Accrual taxation of FAPI earned through a controlled foreign affiliate or foreign investment entity;

c) Deferral treatment of income earned through foreign corporations (with the exception of the accrual treatment of FAPI);

d) "Exemption" or "credit" treatment of dividends from foreign affiliates, distinguished on the basis of a tax treaty or TIEA and the character of foreign income. ${ }^{9}$

As mentioned earlier, there is little actual difference between the "exemption" and "credit" system in terms of Canada's tax revenue collection. In the absence of empirical evidence to the contrary, it is reasonable to assume that taxable dividends are repatriated only when they

\footnotetext{
9 For an overview, see Li, Cockfield and Wilkie, International Taxation in Canada (2006), chapters 11 and 13. For some insights on the historical background of the current rules, see Alan Short, "Conference on the Report of the Royal Commission on Taxation (Canadian Tax Foundation) 1967, 329; and Alan Short, "International Tax Provisions," Twenty-Second Tax Conference (1970) 171.
} 
carry enough credits to eliminate any Canadian tax payable or when the Canadian corporation is not in a tax-paying position in the first place. Therefore, in effect, dividends from foreign affiliates are not taxed at the corporate level.

\section{PRinciples UNDERLYING THE CURRENT SySTEM}

There is no simple general principle that applies to all international tax policy issues. However, there are several principles that apply to the current system, the most basic of these principles are arguably the abilityto-pay and tax entitlement.

\section{A. OVERVIEW OF THE PRINCIPLES}

The Ability-to-Pay principle. The ability-to-pay principle is the foundation of progressive personal income taxation. ${ }^{10}$ Since taxes are ultimately borne by individuals, it has been generally considered fair to spread the tax burden among individual taxpayers on the basis of comparative economic well-being, often referred to as ability-to-pay. For example, the Carter Commission regarded equity (or fairness) as a major policy objective. ${ }^{11}$ The Carter Commission distinguished between "horizontal equity," which requires that persons "in similar circumstances" bear the same taxes, and "vertical equity," which requires that persons in different circumstances bear "appropriately different" taxes. ${ }^{12}$ Both dimensions of equity required that tax be levied in accordance with "ability to pay." Although there are many occasions when ability-to-pay must yield to other policy

\footnotetext{
${ }^{10}$ See Canada, Royal Commission on Taxation (Chair: K. Carter), Report, vol. 4 (Ottawa: Queen's Printer, 1966 (hereinafter “Carter Report”), at 483-84; and Fair Tax Commission (Ontario), Fair Taxation in a Changing World (University of Toronto Press, 1993), at 44-48. See also Edwin Seligman, Essays in Taxation (The Macmillan Company, 1931), 338 ; and Clifton Fleming, Jr., Robert J. Peroni, and Stephen E. Shay, "Fairness in International Taxation: The Ability-to-pay Case for Taxing Worldwide Income” 5 Flf. Tax Rev. 299.

${ }^{11}$ This is the view of the Carter Commission. See Carter Report, ibid, vol. 1, at 4-5.

${ }^{12}$ Ibid, vol. 1, 4-5. This view is generally shared. See Peter Hogg, Joanne Magee and Jinyan Li, Principles of Canadian Income Tax Law (6 ${ }^{\text {th }}$ ed) (Carswell 2006), ch.2.
} 
considerations (such as efficiency, simplicity and competitiveness), it is often given weight in the domestic tax policy process.

The ability-to-pay principle underlies the design of the basic outbound tax rules. The worldwide tax regime required by section 3 of the Income Tax Act (i.e., including a resident's foreign income in computing the taxpayer's income) reflects this principle. An income tax based on the ability-to-pay principle is inherently global. ${ }^{13}$ The same principle also demands that foreign taxes paid on the foreign income reduces the taxpayer's ability-to-pay and should be allowed to reduce the Canadian tax liability.

The ability-to-pay principle generally applies at an individual level and not to corporations. Corporations and other intermediaries are legal entities used to earn income for the benefit of individuals. Income taxes paid by corporations are generally shifted to shareholders, workers, suppliers, and customers. The residence of a legal fiction (i.e., a corporation) is artificial, and the income level of a corporation bears little connection with the ability to pay of its shareholders.

Corporations are separate entities. Corporations are "persons" under the Income Tax Ac. They are generally regarded as taxpayers separate from their shareholders. A corporation is a Canadian resident if it is incorporated in Canada or has its place of central management and control in Canada. Canadian resident corporations are taxable on their foreign income earned directly. However, if foreign income is earned through a foreign corporation, that income is generally not taxable in Canada to the Canadian shareholder.

The "separate entity" principle can effectively cancel the ability-to-pay principle if left unchecked: individuals can choose to earn foreign income through a non-resident corporation. The FAPI rules function as such checks and protect the integrity of the ability-to-pay in Canada.

13 See Fleming, Peroni and Shay, supra note 10; Carter Report, supra note 10, at 503; McIntyre, infra note 38; David Bradford, Blueprints for Basic Tax Reform (2d ed., rev. 1984), at 90; Musgrave, "Sovereignty, Entitlement, and Cooperation in International Taxation” 26 Brooklyn J. Int'l L. 1335 (2001), at 1336-7. 
The Tax Entitlement Principle. The tax entitlement principle calls for an equitable sharing of the international tax base between nations in accordance with each nation's tax entitlement. ${ }^{14}$ The theoretical foundations for this principle are the economic allegiance theory, ability to pay, and the benefit theory. ${ }^{15}$

Under this principle, a residence country is entitled to tax foreign income on the grounds that: (a) residents owe tax allegiance in return for the rights and privileges that they receive as residents (including those afforded to a corporation by its country of registration); (b) the tax is, in nature, a payment for productivity-enhancing benefits provided by the country of residence to its own factors of production prior to transfer abroad; (c) it is necessary to achieve equitable tax treatment of resident taxpayers by making all income, wherever earned, subject to tax, consistent with the accretion [ability to pay] principle. ${ }^{16}$ A source country is entitled to tax income arising within their borders, including that accruing to foreign investors. A country is permitted "to share in the gains of foreign-owned factors of production operating within its borders, gains that are generated

${ }^{14}$ The principle of tax entitlement underlies the concept of "inter-nation equity", which was originally developed and advocated by Peggy Musgrave and Richard Musgrave. See Peggy B Musgrave and Richard A. Musgrave, 'Inter-Nation Equity,' in Richard M. Bird and John G. Head, eds., Modern Fiscal Issues (Toronto: University of Toronto Press, 1972) 63-85, at 68; Peggy B. Musgrave and Richard A. Musgrave, 'Fiscal Coordination and Competition in an International Setting,' in L. Eden, ed., Retrospectives on Public Finance (Durham, NC: Duke University Press, 1991) 61-85, at 65-6; Peggy Musgrave, "Sovereignty, Entitlement, and Cooperation in International Taxation," Brooklyn J. Int'l L. 26 (2001) 1335-1356; and Peggy Musgrave, "Combining Fiscal Sovereignty and Coordination: National Taxation in a Globalizing World," in Inge Kaul and Pedro Conceicao, ed. The New Public Finance Responding to Global Challenges (Oxford University Press 2006) 167. Other scholars and their work include: Nancy Kaufman, 'Fairness and the Taxation of International Income,' Law and Policy in International Business 29 (1998):145-203; Klaus Vogel, 'World-wide vs. Source Taxation of income - A Review and Reevaluation of Arguments,' in Influence of Tax Differentials on International Competitiveness: Proceedings of the VIIIth Munich Symposium on International Taxation (Deventer, Boston: Kluwer Law and Taxation Publishers 1991), 160-61; Jinyan Li, Taxation in the Age of Electronic Commerce: A Comparative Study (Toronto, Canadian Tax Foundation, 2003), ch.12.

15 Kaufman, ibid, at 188 (suggesting that Musgrave's entitlement principles need a foundation in a theory of justice and that "economic allegiance" should be the foundation of a nation's competence in taxation and inter-nation equity).

${ }^{16}$ See, e.g., Peggy Musgrave, “Combining Fiscal Sovereignty and Coordination” (2006), supra note 14 , at 168 . 
in cooperation with its own inputs, whether they be natural resources, an educated or low-cost workforce, or proximity to a market."17 In other words, source country's tax entitlements arise from "economic rent" -the source country's tax "may be thought of as a national return to the leasing of these complementary factors to nonresident investors or temporary workers," or a quid pro quo payment for cost-reducing, profit-enhancing services provided by the source country. ${ }^{18}$ Source taxation in accordance with the tax entitlement principle has been "the bedrock of most international tax treaties."19

Under the tax entitlement principle, Canada is entitled to tax its Canadian residents in respect of their foreign income. However, this entitlement is secondary to the foreign source country's entitlement. The international consensus is that the source country's tax entitlement to business profit is much stronger than to investment income. For example, Article 5 of the OECD Model Convention allows the source country unlimited scope of taxation once the threshold of permanent establishment is satisfied. In contrast, the source country's tax jurisdiction over dividends, interest, royalties and capital gains is restricted (Art.10 and Art. 11 of the OECD Model Convention) or totally removed (e.g., Art 12 of the OECD Model convention). The Canadian outbound tax rules generally recognize the source country's prior tax claim by allowing foreign taxes be reduced from Canadian tax otherwise payable.

Tax Neutrality. As a general principle, taxes should be neutral. ${ }^{20}$ Canadian outbound tax rules are thus required not to distort Canadian companies' decision to invest at home or abroad. It could also be stretched to mean that Canadian tax rules should not impede Canadian companies' competitiveness by imposing tax costs that are not borne by their

\footnotetext{
17 Ibid.

18 Ibid.

${ }^{19}$ Peggy Musgrave, “The OECD Model Tax Treaty: Problems and Prospects," Columbia J. of World Business (Summer 1975) 29.

20 The Carter Commission argued, and many experts agree, that the tax system should be "neutral". What is meant by a neutral system is one that is "designed to bring about a minimum change in the allocation of resources within the private sector of the economy": Carter Report, supra note 10, vol. 2, 8.
} 
competitors from other countries. ${ }^{21}$ In international tax debates, this principle of neutrality has been largely discussed in terms of CEN, CIN and recently CON.

Tax expenditures versus normative system. The Income Tax Act contains two general types of provisions: normative or benchmark provisions and tax expenditures. Tax expenditure provisions are generally those that deviate from the norm in order to promote a specific policy objective. ${ }^{22} \mathrm{~A}$ tax expenditure is evaluated on its merits as if it were a separate assistance programme by asking: How much does it cost? Does it fulfil its objectives? Who benefits from it? Because tax expenditure provisions are intended to be non-neutral, it is futile to justify them on ground of neutrality.

\section{B. RATIONALIZING THE FAPI ACCRUAL REgIME}

The FAPI regime applies, in general, income that is mobile or lacks any "intrinsic" or "natural" connection with the source country. It can be earned through the "simple formal expedient of foreign incorporation" 23 in tax friendly jurisdictions. The FAPI rules are thus "anti-avoidance rules" intended to protect the Canadian tax base. The scope of the Canadian tax base is determined normatively by the ability-to-pay principle and tax entitlement principle. The ability-to-pay principle requires taxpayer's income to include foreign income. Because of the inherently mobile nature of FAPI, the foreign source country's tax entitlement over FAPI is limited. Canada, as a residence country of the investor, shares the jurisdiction to

${ }^{21}$ Scott Wilkie, Robert Raizenne, Heather I. Kerr, and Angelo Nikolakakis, "The Foreign Affiliate System in View and Review," Corporate Management Report (Canadian Tax Foundation, 1993), 2:1-72 (noting that a basic issue in outbound taxation is whether "whether it is important to try to ensure that Canadians conducting foreign commercial operations through foreign corporations are not impeded by business costs, in the form of Canadian taxes, that their competitors do not face”.

${ }^{22}$ Surrey, Pathways to Tax Reform: The Concept of Tax Expenditures (1973) and Surrey and McDaniel, Tax Expenditures (1985) are the seminal works on the topic.

${ }^{23}$ An exempt surplus account also includes inter-affiliate dividends traced to exempt surplus, tax-free portion of capital gains, as well as taxable capital gains from the disposition of "excluded property" (largely assets used in carrying on active business activities). 
tax FAPI. The accrual taxation of FAPI is also consistent with the principle of neutrality as it removes the tax incentives for artificially "sourcing" FAPI to a foreign jurisdiction. ${ }^{24}$

\section{RATiOnALizing The DeferRAL Regime}

The deferral regime is consistent with the separate entity principle. The foreign source country's tax entitlement to business income takes precedence over Canada's entitlement to tax the Canadian corporation. Canada taxes such income only when it is paid to individual shareholders and applies the ability-to-pay principle at this level. In essence, the exemption system recognizes the foreign country's entitlement to tax the income $^{25}$ and Canada's entitlement to tax the individual investors.

The deferral system arguably violates the principle of neutrality as it favors earning foreign income through a foreign subsidiary as opposed to a foreign branch and favors earning foreign income as opposed to Canadian income. In effect, however, such tax bias disappears where the foreign income is taxed in the foreign country at a level equal to the Canadian tax. When a country's tax rate is much lower than the Canadian rate, if the investment conditions are similar in Canada and the foreign country, the deferral system encourages investment in the foreign country. If the investment conditions are different at home and abroad, it is difficult to assess the effect of the tax rules on the investment location. ${ }^{26}$

\section{NATURE OF THE EXEMPTION SYSTEM}

The current exemption system can be rationalized as a proxy for the deferral with credit system, a tax expenditure, or a normative rule. Under

${ }^{24}$ This has been typically phrased as promoting CEN. See Wilkie at al, supra note 21, at 2:27.

${ }^{25}$ Ibid., at 2:10.

${ }^{26}$ For a recent study by the OECD, see Tax Effects on Foreign Direct Investment No.17: Recent Evidence and Policy Analysis (2007) (OECD, Paris). 
the proxy view, ${ }^{27}$ where a foreign country's tax system is comparable to Canada's (this is assessed by the existence of a tax treaty), the credit system will not generate any further tax revenue in Canada. Hence, it is simpler to just "exempt" the dividends from Canadian tax. This view assumes the deferral with credit as the "normative system". Historically, this view is correct.

Under the tax expenditure view, ${ }^{28}$ the exemption system is a deliberate violation of tax neutrality in order to enhance the competitiveness of Canadian companies. The recent broadening of the exemption system to countries that have concluded a Tax Information Exchange Agreement (TIEA) with Canada seems to view the exemption system as an "inducement" to encourage tax information exchange with tax haven jurisdictions. The tax expenditure view also assumes that the deferral with credit is the norm. The underlying assumption is that there must be an underlying normative tax system and an expected level of tax in the foreign country in order for that country to become entitled to the cession of Canadian tax. However, the extension of the exemption system to TIEA countries (zero or low-tax jurisdictions) seems to undermine such an assumption.

Can the exemption system be viewed as part of the normative system? If the analysis is focused on the formal rules of the Income Tax Act, the answer is "no": Dividends from a FA are included in income (s.90), which is then reduced by deducting the amout of "exempt" dividends. On the other hand, the answer is "yes" if the analysis is focused on the substantive effect of these rules: dividends received by Canadian corporations from their FAs are not actually taxed in Canada (whether or

${ }^{27}$ Brian J. Arnold, “”Unlinking Tax Treaties and the Foreign Affiliate Rules: A Modest Proposal” (2002) vol.50, no.1 Canadian Tax J. 607-29; Wilke et al, supra note 21, 2:27 (referring to Department of Finance justification for the partial exemption system. Whether the foreign country has a treaty with the home country is suggested as a way of "limiting" the exemption system in Michael J. Graetz and Paul W. Oosterhuis, "Structuring an Exemption System for Foreign Income of U.S. Corporations" (2001) Vo.54 National Tax J. 771.

${ }^{28}$ See, for example, Angelo Nikolakakis, “Exempt Surplus: What's the Problem? A Reply to Brian Arnold” (2002) vol.50, no.4 Canadian Tax J. 1354-77. For a detailed critique of the US rules, see J. Clifton Fleming, Jr. and Robert J. Peroni, "Reinvigorating Tax Expenditure Analysis and Its International Dimension,” (2008) vol.27 Virginia Tax Rev. 439. 
not they are exempt dividends). The exemption system is thus a de facto norm. ${ }^{29}$

In terms of fundamental tax principles, the "normative" view is defendable. As long as the Income Tax Act recognizes the general principle of taxing corporations as separate entities, income earned by a corporation is "exempt" from tax at the individual shareholder level until dividends are received. The ability-to-pay principle overrides this separate entity principle only in cases where the corporation is used as a holding vehicle for earning passive income. In general cases, as far as the individual shareholder is concerned, corporate business income is "exempt" from tax, irrespective of whether the income is earned through a foreign corporation.

The exemption system is consistent with the tax entitlement principle. The country in which business activities are conducted has clear and overwhelming claims over the taxation of such income. In addition to providing an enticing business and investment environment, the source country's resources (natural and labour) and market conditions are perhaps the economic reasons why Canadian corporations carry on business activities in that country.

A "normative" view of the exemption system has implications for the design of other outbound tax rules. One example is interest deductibility. The current paragraph 20(1)(c) of the Income Tax Act has been interpreted to allow full deduction of interest on money borrowed to earn effectively "exempt", but formally taxable, dividends. Such interpretation would be difficult to sustain if dividends are actually exempt as part of the normative system. The fungibility of money makes interest expense allocation inherently difficult. Assuming interest can be allocated to earning dividends from foreign affiliates, the deductibility of such interest would need to be justified as a "tax expenditure". ground.

${ }^{29}$ Wilke et al, supra note 27. 


\section{APPROACH TO REFORM}

\section{A. Moving Away from the “BAttle of Neutralities” 30}

The Consultation Paper recognizes that capital export neutrality (CEN), capital import neutrality (CIN) and capital ownership neutrality (CON) may influence the choice between an exemption system and a deferral with credit system for the taxation of affiliates of Canadian corporations. International tax literature has recently been preoccupied with efficiency and welfare maximization, ${ }^{31}$ predominantly from a one-country perspective. $^{32}$ However, it is problematic to regard CEN, CIN and CON as key considerations for international tax policy. ${ }^{33}$ As recognized by the Canadian Tax Panel, "fulfilling the three neutrality standards with a single

${ }^{30}$ This term is borrowed from Edward D. Kleinbard, "Throw Territorial Taxation from the Train”, Tax Notes, February 5, 2007 547-564, at 555.

${ }^{31}$ This is noted by legal scholars, such as J. Clifton Fleming, Jr., Robert J. Peroni and Stephen E. Shay, 'Fairness in International Taxation: The Ability-to-pay Case for Taxation Worldwide Income, Florida T. Rev. 5 (2001), 299; and Michael J. Graetz, 'Taxing International Income: Inadequate Principles, Outdated Concepts, and Unsatisfied policies,' Brooklyn J. Int'l L 26 (2001), 1357. For an overview of the literature on international tax neutrality, see Fadi Shaheen, 'International Tax Neutrality: Reconsiderations,' Va. Tax Rev. 27 (2007), 203; James R. Hines Jr., 'The case Against Deferral: A Deferential Reconsideration,' Nat'l Tax J. 52 (1997 385; and Mihir A. Desai and James R. Hines Jr., 'Evaluating International Tax Reform,' Nat'l Tax J. 56 (2003) 487.

${ }^{32}$ Professor Michael Graetz remarked in 2001 that "this nation's international tax policy [should instead] be fashioned to advance the interests of the American people": see Graetz, ibid. Professor Shaviro maintains that worldwide welfare should remain a normative standard in US international tax policy because capital export neutrality and capital import neutrality are, in fact, a tool for promoting national welfare in the broader setting of a global prisoner's dilemma. See Daniel Shaviro, "Why Worldwide Welfare as a Normative Standard in U.S. Tax Policy?” (2006-2007) 60 Tax Law Review 155.

${ }^{33}$ The CEN generally requires current taxation of foreign income with a full credit for foreign taxes paid. To the extent that foreign taxes are less than domestic tax, the tax base is shared between the source country and the residence country of the shareholder. CIN and CON call for the primary or exclusive taxation of business income in the source country. This is often referred to as the "exemption" system or territorial system. In practice, no country has adopted a pure credit system or a pure exemption system. The mix of the two systems attempts to balance between CEN and CIN/CON. 
set of tax rules is impossible". ${ }^{34}$ There are disagreements as to what is needed to satisfy CIN or CEN. Traditionally, CEN is considered satisfied by the accrual taxation or deferral with credit system, ${ }^{35}$ and CIN is satisfied by the exemption system. ${ }^{36}$ Recently, some scholars argue that exclusive source-based taxation (or territorial taxation) "seems to be a theoretically, practically, and politically superior means for achieving CEN." "37 The current international consensus is a compromise of CIN and CEN. As principles of international taxation, CEN and CIN fail to explain the international income tax system that actually exists. ${ }^{38}$

The conflicts between CIN and CEN cannot be reconciled in the absence of harmonization of every country's tax rates. The Carter Commission argues that neutrality requires tax harmonization between nations so that each individual is unaffected, from a tax viewpoint, by citizenship, residence, and the locations of property, business, and employment. ${ }^{39}$ Of course, such harmonization is possible only if all countries provide the same public expenditures mix, finance with the same taxes at the same rates, and adjust the taxes simultaneously. Since one of such criteria is unlikely to be met in practice and that therefore international neutrality cannot be achieved. Even if tax harmonization were possible, the Commission notes that ax revenues must still be allocated between source

${ }^{34}$ Consultation Paper, supra note 1 , at 11.

${ }^{35}$ See Peggy B. Musgrave, United States Taxation of Foreign Investment Income, at 121 (arguing that only unlimited foreign tax credit system satisfies CEN). Others have defended the "deferral plus credit" (with limitations) on grounds of CEN. See, for example, US Treasury Department, the Deferral of Income Earned Through U.S. Controlled Foreign Corporations: A Policy Study (2000), 23-26.

${ }^{36}$ Shaheen, supra note 31.

${ }^{37}$ Ibid, at 225-8. According to Shaheen, the pure residence-based worldwide taxation system satisfies CEN only when global uniformity with respect to tax systems is achieved.

${ }^{38}$ Michael McIntyre writes: "None of these guidelines [US tax guidelines, including worldwide taxation, source taxation, foreign tax credit, etc.] relies on the so-called principles of capital export neutrality or capital import neutrality, notwithstanding the usual prominence of those principles in discussions of international tax regimes. In my view, capital export neutrality is a secondary goal. Neutral treatment of capital flows cannot be achieved fully without subversion of the income tax through an exemption for capital income. Capital import neutrality is a lobbying position, not a coherent tax policy goal." See "Guidelines for Taxing International Capital Flows: The Legal Perspective” 46 National Tax J. 315 (1993), at 318.

${ }^{39}$ Carter Report, supra note 10, vol. 4, at 491-96. 
and destination countries, and in a world of other distortions international neutrality may not be a sensible goal. ${ }^{40}$

The practical implications of CIN and CEN are not as significant as they appear. The apparent difference between deferral with credit system (CEN-based) and the exemption system (CIN based) results in little real difference where foreign business income is not repatriated (that is, if the deferral lasts long enough) because of the time value of money. There is little tax revenue generated from foreign business income whether or not an exemption or a credit system is used. ${ }^{41}$ In certain circumstances, the credit system produces tax results that are better than the exemption system. $^{42}$

On the one hand, "policy prescriptions under CEN, as well as CIN and CON cannot provide production efficient results in all cases” because CON and CIN ignore effects of corporate tax-planning on effective tax rates and miss the fact that various forms and degrees of income shirting will result in different effective tax rates on profits for different competing investors. ${ }^{43}$ On the other hand, the CEN or CIN arguments can justify almost any proposal of reform: "[E]vry traditional discussion concludes by asserting that whatever policy is being proposed represent a fair balance

${ }^{40}$ Ibid.

41 International Taxation, Report of the Technical Committee on Business Taxation (1997), (the "Technical Committee Report), ch.6. For a review of this report, see Nick Pantaleo and Scott Wilkie, “Taxing Foreign Business Income," (1998) Corporate Management Conference Report (Canadian Tax Foundation) 8:1-44.

42 See, for example, Lawrence Lokken, "Territorial Taxation: Why Some U.S. Multinationals May Be Less Than Enthusiastic About the Idea (and Some Ideas They Really Dislike)” (2006) Vol.59 S.M.U.L.Rev. 751-72 (discussing why the credit system often allows US multinational corporations to achieve US tax results more favorable than they could obtain under an exemption system). Lokken attributes such favorable results to the numerous tax minimization techniques used by US corporations, including one technique that is used to separate foreign income taxes from income on which those taxes were imposed through the use of hybrid entity under the check-the-box rules.

${ }^{43}$ OECD Report on Tax Effects on Foreign Direct Investment, supra note 26, at 18. See also Rosanne Altshuler and Garry Grubert, "Governments and Multinational Corporations in the Race to the Bottom,” 41 Tax Notes Int'l 459 (Feb. 6, 2006); Garry Grubert and Rosanne Altshuler, "Corporate Taxes in the World Economy: Reforming the Taxation of Cross-Border Income,” at ftp://snde.rutgers.edu/Rutgers/wp/2006-26.pdf. 
between those two irreconcilable objectives [CIN and CEN], in every case based largely on the author's preexisting intentions." 44

To the extent that the neutrality theories are helpful at all, their utility is largely limited to the choice between the credit system and exemption system. As far as Canada is concerned, the option of full credit system does not really exist. The CIN/CON or CEN arguments provide little insight on the debate on the choice of expanding the current partial exemption or full exemption, which is the real debate in Canada at the moment.

\section{B. A “PRINCIPLED” APPROACH}

A more principled approach will take into account the fundamental principles that underlie the apparently complex rules of outbound taxation. Such approach can help policy makers navigate among the various, sometimes conflicting, policy considerations, including the various conflicting neutralities, competitiveness, simplicity, fairness, and practical constraints. $^{45}$ It should also help identify the normative and tax expenditure elements of the current system.

In terms of the structure of the Canadian outbound tax system, a principled approach would support a simplified, full exemption system and a broader accrual system for FAPI. ${ }^{46}$ Eliminating deferral with credit system will not violate any tax principles. It would significantly simplify the outbound tax

\footnotetext{
${ }^{44}$ Kleinbard, supra note 30, at 555.

45 "Clearly articulated principles" are called for by Alvin C. Warren, Jr., "Commentary" (Spring 1991), 9 The American J. of Tax Policy 145-8, at 147-8.

46 The Consultation Paper is focused on the taxation of Canadian corporations in respect of income earned through foreign affiliates, namely active business income and FAPI. With respect to active business income, the Consultation Paper lists four alternative choices in how the income is taxed in the parent company's country: accrual or worldwide basis of taxation; deferral with credit; partial exemption and partial deferral with credit (the "Canadian system"); and full exemption. The Consultation Paper suggests moving towards the full exemption system, and acknowledges that "there appears to be little debate that taxing FAPI on an accrual basis is appropriate": Consultation Paper, supra note 1, at 2.43.
} 
system as it would be unnecessary to compute the surplus accounts and track foreign taxes underlying the dividends. As discussed above, the difference between "partial exemption" and "partial deferral with credit" within the Canadian system is more formal than real. There is little real difference between the current exemption and credit system from the point of tax revenue collected in Canada. There are no clear "principled" justifications for the partial deferral with credit system: the ability-to-pay principle is no more satisfied by the credit than the exemption system; the tax entitlement principle that underlies Canada's cession of tax jurisdiction to the foreign country does not distinguish between treaty or non-treaty countries; and the separate entity principle is applicable outside the FAPI system.

Assuming that both the exemption regime and accrual regime apply to foreign affiliates (i.e., by eliminating the "control" requirement in the accrual regime), there is really nothing beyond accrual taxation of FAPI and exempt treatment of dividends. As far as Canadian tax policy is concerned, the key is to define and protect the Canadian tax base in such a manner that the tax rules do not distort investment location choices.

\section{POLICY CONCERNS}

A full exemption system does not represent a major shift in Canada's tax structure or policy for the reasons discussed earlier. Nonetheless, concerns can be raised over the possibility that it will result in further erosion of the Canadian tax base and relocation of domestic operations to countries with lower taxes.

The concern with relocating investment to foreign low-tax jurisdictions already exists. The current partial exemption system already covers some well-known low-tax jurisdictions, such as Barbados. In fact, Barbados is the $3^{\text {rd }}$ largest recipient of Canadian outflow foreign direct investment (FDI). ${ }^{47}$ On the other hand, more than half of Canadian outbound FDI in

${ }^{47}$ Canadian Foreign Direct Investment Abroad, by Top-10 Destinations, 2006 (Billions CAD): United States (42.7\%), UK (11.3), Barbados (7.3\%), Ireland (4.7\%), France (3.2\%), Bermuda (3\%), Netherlands (2.3\%), Hungary (1.9\%), Australia (1.8) and Germany (1.8\%). Source: Statistics Canada, International investment position, Canadian 
2006 was in the United States (42.7\%) and United Kingdom (11.3), which are "high-tax" countries.

It is difficult to estimate the extent to which a full exemption system would have on the outbound FDI flows. It is unclear about whether the Canadian outbound FDI is a substitute or complement for domestic investments. To the extend that Canadian outbound FDI is made for nontax reasons, such as accessing lower costs, natural resources, or local market, the FDI is arguably not substituting domestic investment. To the extent that FDI substitutes for domestic investment and it is driven by Canadian tax reasons, then, the issue is serious. Empirical research is needed. ${ }^{48}$

A related concern is the further loss of the tax base. Arguably, the current "deferral with credit" (or taxable dividends) regime does not really produce much tax revenue in Canada. As such, a move to a full exemption will not further erode the Canadian tax base. That does not mean, however, that base erosion is not a serious concern. The fact that Barbados is the third largest recipient of Canadian FDI clearly indicates the "tax" motivation behind the initial choice of destination.

A further related concern is the "race-to-the-bottom" international tax competition. Because a full exemption system would leave the taxation of corporate non-FAPI profit to be determined solely by the source country, FDI host countries would compete in lowering the tax burden in order to attract FDI. It is controversial whether such competition is effective in actually affecting the FDI location decisions or economically efficient. ${ }^{49}$ Assuming that host-country tax competition to attract foreign "direct" investment is a reality, which may be defendable on ground of national tax

direct investment abroad and foreign direct investment in Canada, by country, annual (dollars), CANSIM Table 376-0051. This data is reproduced in Competition Policy Review Panel, Consultation Paper, “Sharpenning Canada’s Competitive Edge”, (2008) http://www.ic.gc.ca/epic/site/cprp-gepmc.nsf/en/00013e.html.

48 This is an empirical question that is beyond the scope of this Article. There is some research indicating the U.S. outbound FDI complements domestic investment and employment.See R. Glenn Hubbard, “Tax Policy and International Competitiveness”, The Tax Magazine, Vol. 82, No.3, March 2004.

${ }^{49}$ See OECD Report on Tax Effects on Foreign Direct Investment, supra note 26. 
sovereignty, ${ }^{50}$ a full exemption system would not be problematic. It would allow FDI host countries, especially low-income developing countries, to use their tax policy as an instrument for promoting FDI and economic development. $^{51}$ On the other hand, a full exemption system, if not complemented by an effective accrual system, may promote "harmful" tax competition in respect of "mobile” investment.

\section{DESIGNING THE EXEMPTION SYSTEM}

This Article argues that a full exemption could be viewed as part of the normative outbound tax system as opposed to a tax expenditure. Under this view, Canada cedes its jurisdiction to tax a Canadian corporation receiving dividends from a foreign affiliate in a way not dissimilar to dividends received by a Canadian corporation from its Canadian subsidiary. The Canadian cession of tax jurisdiction can be unconditional as long as the distinction between "direct" and "portfolio" investment is maintained. Other than the rules defining "foreign affiliate," the rules for tracking the amounts in support of the distinction between "taxable" dividends and "exempt" dividends would become redundant.

\footnotetext{
50 The tax sovereignty of the FDI host country presumably includes the right to use tax policy to attract FDI, as long as it does not constitute "harmful" tax competition. In an ideal world, a "tax-neutral" system adopted by capital exporting countries would discourage FDI host countries (especially developing countries) from engaging in tax competition; see Grubert and Altshuler, supra note 41. In reality, many developing countries use tax incentives to entice FDI. Under certain conditions, the tax incentives can be effective in attracting FDI. For a case study of China, see Jinyan Li, "The Rise and Fall of Chinese Tax Incentives and Implications for International Tax Debates,” (2007) v. 8 Florida Tax Rev. 670.

${ }^{51}$ To the extent that a FID host country is not in a position to use tax policy effectively (e.g., offer tax incentives that do not actually affect the location decision of investors or tax incentives were abused by taxpayers), a full exemption system does nothing to assist the host country. There are also inter-nation equity implications when the tax incentives result in a "reverse" distribution of tax base from a low-income country to a high-income country. Presumably, such inter-nation "inequity" is more serious under a "credit" system than an "exemption" system. See Li, ibid.
} 


\section{A. ELIGIBLE TAXPAYERS}

The proposed full exemption system would apply to Canadian resident corporations, not individuals, receiving dividends from a "foreign affiliate". Excluding individuals from the system is necessary under the ability-to-pay principle. Individual shareholders of a resident corporation will be taxable on the dividends paid out of the foreign income earned by the corporation. The "exemption" system is thus limited at the corporate level only.

\section{B. ELIGIBLE FOREIGN CORPORATIONS}

The definition of "foreign affiliate" can be revised to reflect "genuine" foreign direct investment. A $10 \%$ voting rights or value threshold would be consistent with international tax norms and similar to the threshold for distinguishing between direct and portfolio investment in a domestic context (i.e. Part IV of the Income Tax Act). This Article also recommends lowering the threshold for FAPI taxation to $10 \%$. As such, there is a built-in "anti-avoidance" mechanism so that the "FA" status would not be used as a means of avoiding Canadian tax.

\section{ELIGIBLE FOREIGN INCOME}

The current partial exemption system is generally limited to active business income earned by a FA in a treaty country. The characterization of income as "active business income" is thus a crucial building block. ${ }^{52}$ FAPI is implicitly excluded. So is income that is neither FAPI, nor active business income. Under a proposed full exemption system, there is no need to define "active business income.” From Canadian tax policy

52 Exempt surplus account also includes inter-affiliate dividends traced to exempt surplus, tax-free portion of capital gains, as well as taxable capital gains from the disposition of "excluded property" (largely assets used in carrying on active business activities). 
perspective, what is important is the accrual taxation of FAPI. Non-FAPI is subject to territorial taxation. ${ }^{53}$

\section{BRANCHES}

The exemption treatment should be extended to non-FAPI income earned by Canadian corporations through a foreign branch. This makes sense where the territorial taxation of business income is accepted as a normative rule and there is no sound policy why this rule should be overruled on ground of ability-to-pay. Including branches in the exemption system is unlikely to erode Canadian tax base. If the business is carried on a country with a comparable tax system, the business income will not attract any Canadian tax because of the foreign tax credit. In the case of business losses, they will not be deducted for Canadian tax purposes.

\section{E. UNLINKING FROM TAX TREATIES}

There would be no need to link the exemption system to tax treaties. The issue of low-tax jurisdictions can be addressed through a re-designed FAPI.

\section{F. OTHER RETURNS FROM FOREIGN AFFILIATES}

This paper suggests that all dividends received by Canadian corporations from their foreign affiliates are exempt from Canadian tax. If the return on equity investment is exempt from tax, a logical question is whether other returns (e.g., royalties and interest) are also exempt from Canadian tax. This question raises a tax neutrality issue as it is biased in favor of equity investment.

53 However, should the redesigned exemption system remain "partial" and some dividends from foreign affiliates remain taxable in Canada, rules similar to the present characterization rules and "surplus" accounting rules would be required. 
On the other hand, the taxation of royalties and interest and non-taxation of dividends in Canada is arguably consistent with the tax entitlement principle. Assuming that the foreign tax law is similar to the Income Tax Act, interest and royalty payments are deductible in computing income, thereby not taxed in that country. The Canadian corporate investor has presumably incurred research and development expenses in developing the property licensed to foreign affiliates, Canada is entitled to tax the royalty income. However, in the absence of specific, new, base-protection rules, Canadian developed intangibles can be transferred offshore so that future royalties will be sheltered from Canadian taxation.

\section{REDESIGNING THE ACCRUAL SYSTEM}

\section{A. TARGETED INCOME - "FAPI”}

The current definition of "FAPI" is intended to capture income that that has no nexus to business activity, is highly mobile and easily shifted to low or no tax jurisdictions. More specifically, FAPI includes:

- passive income from property;

- income from a business that is not really "active", which is determined by either the speculative, isolated nature of the activity, or the main source of income being investment;

- income from "mobile" business activities, such as services ${ }^{54}$ and sales or trading; 55

- income that is actually originated from Canada, but deflected to a foreign jurisdiction. ${ }^{56}$

The FAPI definition also includes, in very simple terms, taxable capital gains on the sale of assets not used in active business and on the sale of shares of affiliates who do not carry on active business. Inter-affiliate payments of investment income do not give rise to FAPI as long as the underlying nature of the income of the group is active (measured by, for

\footnotetext{
${ }^{54}$ S.95(2)(b) of ITA.

${ }^{55} \mathrm{~S} .95(2)(\mathrm{a} .1)$ of ITA.

${ }^{56}$ S.95(2)(a.2), (a.3) and (a.4) of ITA.
} 
example, the deduction of the payment in computing active business income).

The current definition with respect to "mobile" income is generally sound. It can be expanded to include more services and sales income. With respect to capital gains, it is worth considering an alternative that FAPI specifically includes taxable capital gains on the sale of assets that produce FAPI and shares whose value is attributable to appreciation of passive assets.

\section{B. TARGETED FOREIGN CORPORATIONS}

Under the current rules, FAPI earned by a foreign corporation is taxable to a resident shareholder (individual or corporation) only in cases where the foreign corporation is "controlled" by the resident (i.e., owning sufficient votes, generally $50 \%$, to elect a majority of the board) ${ }^{57}$ or if the foreign corporation is a foreign investment entity.

In theory, all FAPI should arguably be subject to accrual tax. In practice, if a resident taxpayer cannot compel the foreign corporation to provide sufficient information on the computation of FAPI and the underlying foreign taxes, it would be difficult for the taxpayer to comply with the rules. The "control" test was originally adopted largely to accommodate this practical concern. However, it is questionable whether the "control" test is still necessary at present. Canadian corporations enjoy the exemption treatment in respect of dividends received from their "foreign affiliates". The definition of "foreign affiliate" requires, in general terms, $10 \%$ ownership of equity investment. In order to qualify for the exemption, Canadian corporations must compute the surplus amounts of each of the foreign affiliate, which presumably requires a great deal of information. The $10 \%$ test does not seem to be a problem. Moreover, the FIE regime imposes accrual tax on income from portfolio investments

57 "Controlled foreign affiliate" is defined under s.95(1) of the ITA. "Control" means "de jure” control: See, eg., Duha Printers (Western) Ltd. V. M.N.R., [1998] 3 C.T.C. 303, 98 D.T.C. 6334 (S.C.C.). 
irrespective of the shareholder's ownership percentage. A lower threshold of $10 \%$ or $25 \%$ is used or proposed ${ }^{58}$ in some other countries. ${ }^{59}$

\section{SAFE HARBOURS}

In order to simplify compliance, the threshold for exemption from the FAPI system can be raised. Another approach might be to exempt a foreign corporation's FAPI from tax if the FAPI is below a defined percentage (say $5 \%$ ) of its total income. ${ }^{60}$

\section{OTHER BASE-PROTECTION RULES}

In addition to FAPI accrual rules, Canada needs to introduce rules that allocate income and expenses to income earned in Canada and income earned in foreign countries. Since only foreign income of a foreign affiliate is eligible for the exemption treatment, in the absence of effective source rules, the exemption system would erode the domestic tax base as a result of income shifting.

\section{A. EXPENSE AlLOCATION}

The need for better allocation rules exists under the current system. A broader exemption system adds more pressure. One of the controversial expenses is interest. In principle, interest expenses incurred to earn taxable income (e.g., FAPI, domestic income, and foreign direct income) are

\footnotetext{
${ }^{58} 10 \%$ was discussed in the UK HM Treasury Report, “Taxation of Companies' Foreign Profits: Discussion Document” (2007), at 4.16. 25\% is mentioned in the New Zealand's International Tax Review: A Direction for Change: A Government Discussion Document" (2006), at 5.26.

${ }^{59}$ For more discussion, see Brian J. Arnold, "Controlled Foreign Corporation Rules, Harmful Tax Competition, and International Taxation,” in 2000 World Tax Conference Report, Report of the Proceedings of the First World Tax Conference: Taxes without Borders (Toronto: Canadian Tax Foundation, 2000) 17:1-26 at 7.

${ }^{60}$ This is the rule in Australia, and proposed in the New Zealand Report, supra note 58, 5.11 .
} 
deductible, whereas interest expenses incurred to earn "exempt" income are not. The challenge is how to allocate interest expenses among the different categories of income and whether interest deductible should be used as a tax subsidy to Canadian companies in respect of their foreign investment. There are no simple technical solutions. ${ }^{61}$

\section{B. INTANGIBLES}

In the case of intangibles, where a Canadian company developed an intangible in Canada and then transfers it to a holding entity in a low-tax jurisdiction, which then licenses it to related foreign affiliates in other countries, the Canadian tax base can be eroded as a result of:

- deductions of research and development costs;

- no gain on the transfer of the intangible to offshore when the fair market value at that time does not exceed the cost;

- there is no deemed royalty to the Canadian developer after the transfer; and

- the royalty earned offshore is deemed not to be FAPI.

The valuation rules and transfer pricing rules can presumably be applied to address the base-erosion issue. Abolishing the inter-affiliate non-FAPI deeming rule is not a complete solution because part of the royalty is likely earned offshore and should not be taxed in Canada. An alternative solution is a new "income source" rule and expense allocation rule for intangibles. The Canadian developer can be deemed to continue to own the intangibles even when the "legal" title has been transferred to the foreign affiliate.

${ }^{61}$ There has been a great deal of debate on interest deductibility in Canada. For some recent literature, see Sandra Slaats, "Financing Foreign Affiliates: An Overview of the Canadian Proposals and the Rules in Selected Countries," (2007) vol.55, No.3 Canadian Tax J. 676; Tamaki, P.K. 2004. "Policy Forum: Thoughts on the Deductibility of Interest and Other Expenses." (2004) col.52 Canadian Tax J. 1121. For some international literature, see Shaviro, D. 2001. "Does More Sophisticated Mean Better? A Critique of Alternative Approaches to Sourcing the Interest Expense of U.S. Multinationals.” 54 Tax L. Rev. 353. 


\section{CONCLUSIONS}

This Article supports the move to a full exemption system and recommends an enhanced FAPI accrual system to complement it. In the absence of meaningful accrual system and income and expense allocation rules, a full exemption system would result in non-taxation of Canadian income shifted abroad, especially income shifted to low-tax jurisdictions. 